\title{
Investigation into metal contamination of the Berg River, Western Cape, South Africa
}

\author{
VA Jackson*, AN Paulse, T van Stormbroek, JP Odendaal and W Khan \\ ${ }^{*}$ Department of Biomedical Technology, Faculty of Health and Wellness Sciences, Cape Peninsula University of Technology, \\ Cape Town 8000, South Africa
}

\begin{abstract}
A recent decline in water quality of the Berg River, Western Cape, South Africa, has led to the investigation into the degree of metal pollution in the river system. This study was conducted over a period of one year, from May 2004 to May 2005. The nitric acid digestion technique was used to extract metals from water, sediment and biofilm samples collected at various points (Site A - agricultural area, Site B - informal settlement and Site C - Newton pumping station) along the Berg River. Metal concentrations were determined using inductively coupled plasma atomic emission spectrometry (ICP-AES). The highest mean metal concentrations recorded were as follows; water samples, $6 \mathrm{mg} \cdot \ell^{-1}$ for $\mathrm{Al}, 14.6 \mathrm{mg} \cdot \ell^{-1}$ for Fe and 18.8 $\mathrm{mg} \cdot \ell^{-1}$ for Mn; sediment samples, $17448.8 \mathrm{mg} \cdot \mathrm{kg}^{-1}$ for $\mathrm{Al}$ and $26473.3 \mathrm{mg} \cdot \mathrm{kg}^{-1}$ for Fe; biofilm samples, $876.8 \mathrm{mg} \cdot \ell^{-1}$ for Al and $1017.5 \mathrm{mg} \cdot \ell^{-1}$ for $\mathrm{Fe}$. The increased availability, or noteworthy incidence of $\mathrm{Al}$ and $\mathrm{Fe}$, could be due to the leaching of metals into the river water from waste and household products associated with the informal settlement and the subsequent settling on sediment. No guidelines were available for metals in biofilms. The highest recorded concentrations in water were for Site C (agricultural area). Recorded concentrations in water fluctuated throughout the study period for most of the metals analysed, but $\mathrm{Al}$ and Fe were consistently above the recommended guidelines as stipulated by the Department of Water Affairs and Forestry and the Canadian Council of Ministers of the Environment.
\end{abstract}

Keywords: metals, river systems, sediment, biofilm, inductively coupled plasma atomic emission spectrometry (ICP-AES)

\section{Introduction}

Metals occur in less than $1 \%$ of the earth's crust, with trace amounts generally found in the environment (Alloway, 1995a). When these concentrations exceed a stipulated limit (South African Bureau of Standards, 2001; World Health Organisation, 1991), they may become toxic to the surrounding environment. Sources of metal contamination include industrial and medical waste (Dorigo et al., 2004), pesticides, petroleum by-products (Mowat and Bundy, 2001), household products, as well as urban and pharmaceutical waste (Brooks et al., 2003). Domestic and household sources of metal contamination generally occur as a result of corrosion of metal plumbing fittings, galvanised roofs and wire fences [zinc (Zn), cadmium (Cd)], and healthcare products, such as $\mathrm{Zn}$ - or selenium- (Se) containing shampoos and Zn-containing baby creams (Alloway, 1995b). Silver paint containing aluminium (Al), Al-coated roofs, saucepans and utensils (Friberg et al., 1986), are also possible sources of contamination.

Natural watercourses can also be contaminated with microorganisms, which inhabit the natural environment in the form of planktonic organisms and sessile biofilms. Under favourable conditions, micro-organisms will generally form a biofilm on any surface exposed to an aqueous environment. These biofilms can be defined as a community of attached microbial cells organised within extracellular polymer matrices (EPS). This EPS assists in the bacterial survival by providing protection against metals, predation and environmental fluctuations, and also provide increased resistance against antimicrobial agents

* To whom all correspondence should be addressed.

푱 +27 21 460-3430; Fax: +27 21 460-3193;

e-mail:204219590@cput.ac.za

Received 4 April 2006; accepted in revised form 26 January 2007.
(Decho, 1990). Biofilms are advantageous in that they encapsulate toxic molecules, such as metals (Costerton et al., 1978), by providing a substrate for them to adhere to, thereby limiting the diffusion of biocides and other toxic molecules across the EPS (De Beer et al., 1994; Huang et al., 1995). This implies that the attached biofilm communities may then be employed in the removal of toxins from aqueous systems, as the biofilms are able to concentrate and bind ions from the passing water (Neu et al., 1992).

The presence of metals in biofilms isolated from the Elbe River in Germany was determined in a study by Friese et al. (1997). They found fractions of several elements from stones and plates incubated in the river. These elements included potassium (K), calcium (Ca), chromium (Cr), manganese $(\mathrm{Mn})$, lead $(\mathrm{Pb})$, nickel $(\mathrm{Ni})$, copper $(\mathrm{Cu})$, zinc $(\mathrm{Zn})$ and iron $(\mathrm{Fe})$. Factors contributing to microbial biodiversity and the tolerance of certain organisms to metals depend on the type of attachment material (e.g. glass, stones, leaves, rocks) the biofilm is isolated from, the age of the biofilm and the concentration of the EPS. In addition, research has indicated that the predominant metals present in streams and lakes are $\mathrm{Zn}, \mathrm{Pb}, \mathrm{Cu}, \mathrm{Fe}$ and $\mathrm{Mn}$ (Geesey et al., 1992; Nelson et al., 1996).

Metal concentrations in environmental samples, may be determined using different analytical techniques. These techniques can be divided into single element analysis, using atomic absorption spectrometry (AAS) and simultaneous multi-element analysis, using ICP-AES and X-ray fluorescence spectrometry (XRF). Vermeiren et al. (1990) investigated ICP-AES as a method of determining the presence of the metals $\mathrm{Cd}, \mathrm{Pb}$, $\mathrm{Cu}$ and $\mathrm{Zn}$ in natural waters. Certain samples were enriched with specific concentrations of the metals, while others were not. Comparison of the results obtained for the enriched and non-enriched river water samples indicated that the technique is accurate in the determination of metal concentrations. 


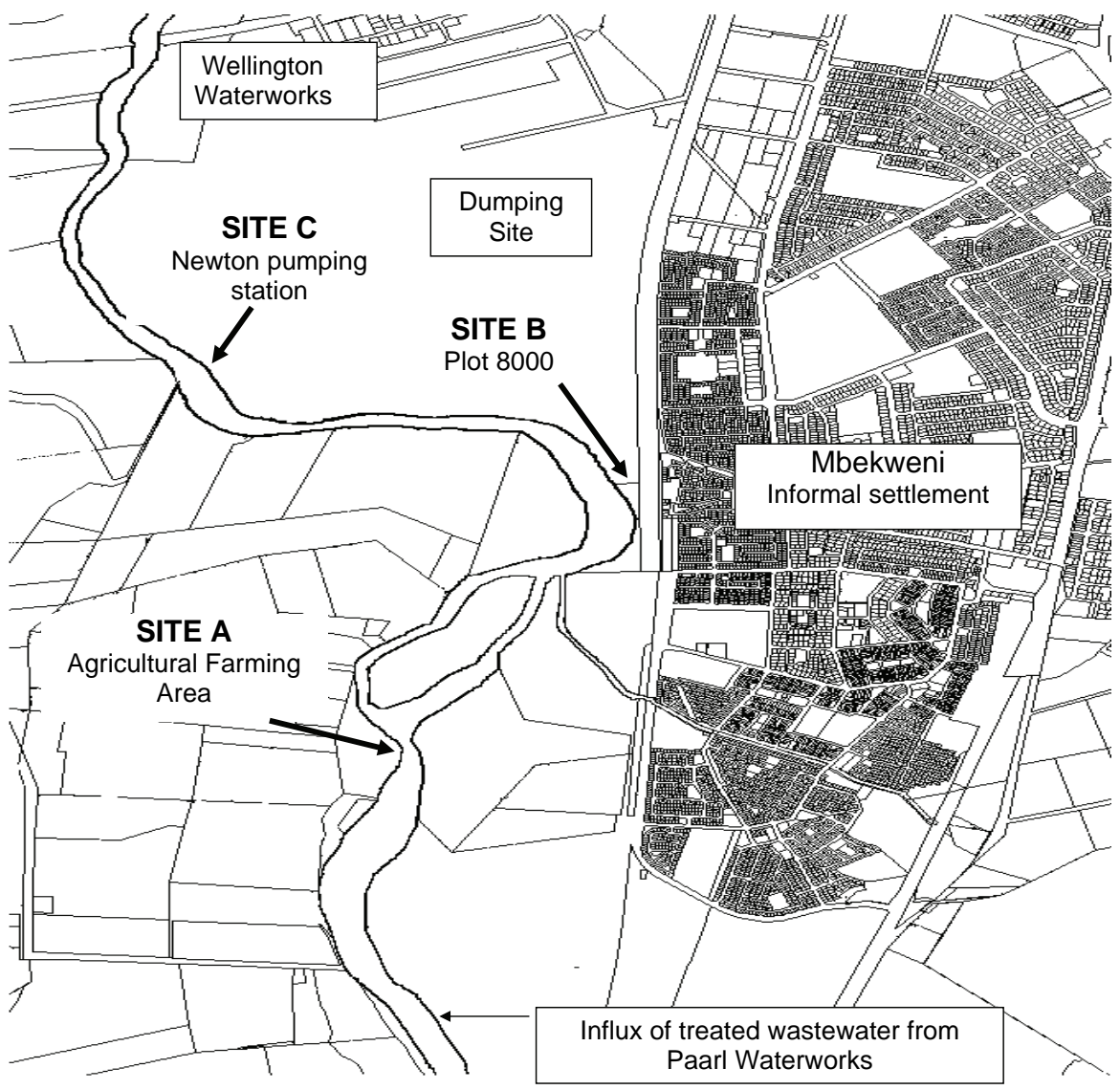

Figure 1

Map of the Berg River indicating the different sampling points: Site A, indicates the agricultural farming area; Site B, indicates Plot 8000, close to the informal settlement of Mbekweni; and Site $C$, the Newton Pumping station farming area) and Site B, known as Plot 8000 (at the informal settlement of Mbekweni). Stormwater drainage pipes from the communities in the settlement discharge into the river at Site B. A $3^{\text {rd }}$ site, Site C (the Newton pumping station), serves as an inlet of storm drainage water and wastewater into the river from the residential area of Newton as well as certain areas of Mbekweni.

\section{Sampling}

Water samples $(200 \mathrm{~m} \ell)$ were collected in sterile $250 \mathrm{~m} \ell$ narrowmouth square polypropylene bottles (Cole-Palmer Instrument Company). The sediment samples were collected in $250 \mathrm{~m} \ell$ plastic containers and consisted of a combination of five different sub-samples $( \pm 15$ cm deep) collected at different locations in a defined perimeter. The biofilm samples were obtained by collecting various materials, such as glass, leaves, stones, rocks, etc. ( 100 g) along each of the different sampling points and storing them in sterile whirl-pack bags. The samples were stored at $4^{\circ} \mathrm{C}$ during transport.

\section{Sonication of collected biofilm samples}

An increase in urbanisation has led to an upsurge in informal settlements in the Western Cape, South Africa, where the inhabitants of these settlements experience a distinct lack of resources. Inadequate sanitation behaviour and a lack of adequate sewage disposal facilities may lead to the leaching of potentially harmful substances, from waste, household products, etc. into the environment. The Berg River was specifically selected due to the increased incidence of pollution recorded within the area in recent times. This increased pollution is of great concern, as the Berg River serves as a water source to towns, cities, rural communities, farms and recreational users in the area (River Health Programme, 2004). The objective of this study was to identify the predominant metals, which occur within the river water, sediment and the biofilm samples isolated from the Berg River (Paarl) in the Western Cape, South Africa.

\section{Materials and methods}

\section{Site description}

Sampling commenced in May 2004 and was conducted over a period of one year until May 2005. Experimental work entailed collecting samples along the Berg River (Western Cape) after 1, 5, 9, 17, 21, 25, 33, 37, 41, 45 and 49 weeks from the commencement of the study (Fig. 1). As indicated in Fig. 1, the samples were collected from Site A (agricultural
Bacterial suspensions were removed from rocks, leaves, glass and stones collected from each representative site, by sonication. Collected material samples $(\sim 100 \mathrm{~g})$ were sonicated for $10 \mathrm{~min}$ in $30 \mathrm{~m} \ell$ sterile distilled water in a UMC5 sonication bath (Instrulab, Inc.). The procedure was repeated at least twice, with fresh sterile d. $\mathrm{H}_{2} \mathrm{O}$ added after each sonication step. The sonicated samples were combined resulting in a total of $60 \mathrm{~m} \ell$ bacterial suspension. The biofilm suspension obtained was used for further analysis.

\section{Metal concentrations in sediment, biofilm and water samples}

To determine the concentrations of $\mathrm{Al}, \mathrm{Zn}, \mathrm{Cu}, \mathrm{Fe}, \mathrm{Pb}, \mathrm{Ni}$ and Mn, sediment samples ( 0.500 to $0.600 \mathrm{~g}$; dry mass), biofilm suspensions $(5 \mathrm{~m} \ell)$ and water samples $(5 \mathrm{~m} \ell)$ were digested with 10 $\mathrm{m} \ell 55 \%$ nitric acid at $40^{\circ} \mathrm{C}$ for $60 \mathrm{~min}$ and then at $120^{\circ} \mathrm{C}$ for 180 min, using a Grant dry-block heater. A blank (control) of $10 \mathrm{m \ell}$ $55 \%$ nitric acid was analysed along with the collected samples, to check for possible contamination. The samples were cooled to room temperature, filtered with Whatman filter paper No 6 into $20 \mathrm{~m} \ell$ volumetric flasks, made up to a volume of $20 \mathrm{~m} \ell$ with distilled water and subsequently filtered for a second time using $0.45 \mu \mathrm{m}$ cellulose nitrate ultrafiltration membrane filters (Whatman). Metal concentrations were determined using ICPAES analysis according to the procedure outlined in Saleh et al. (2000). 

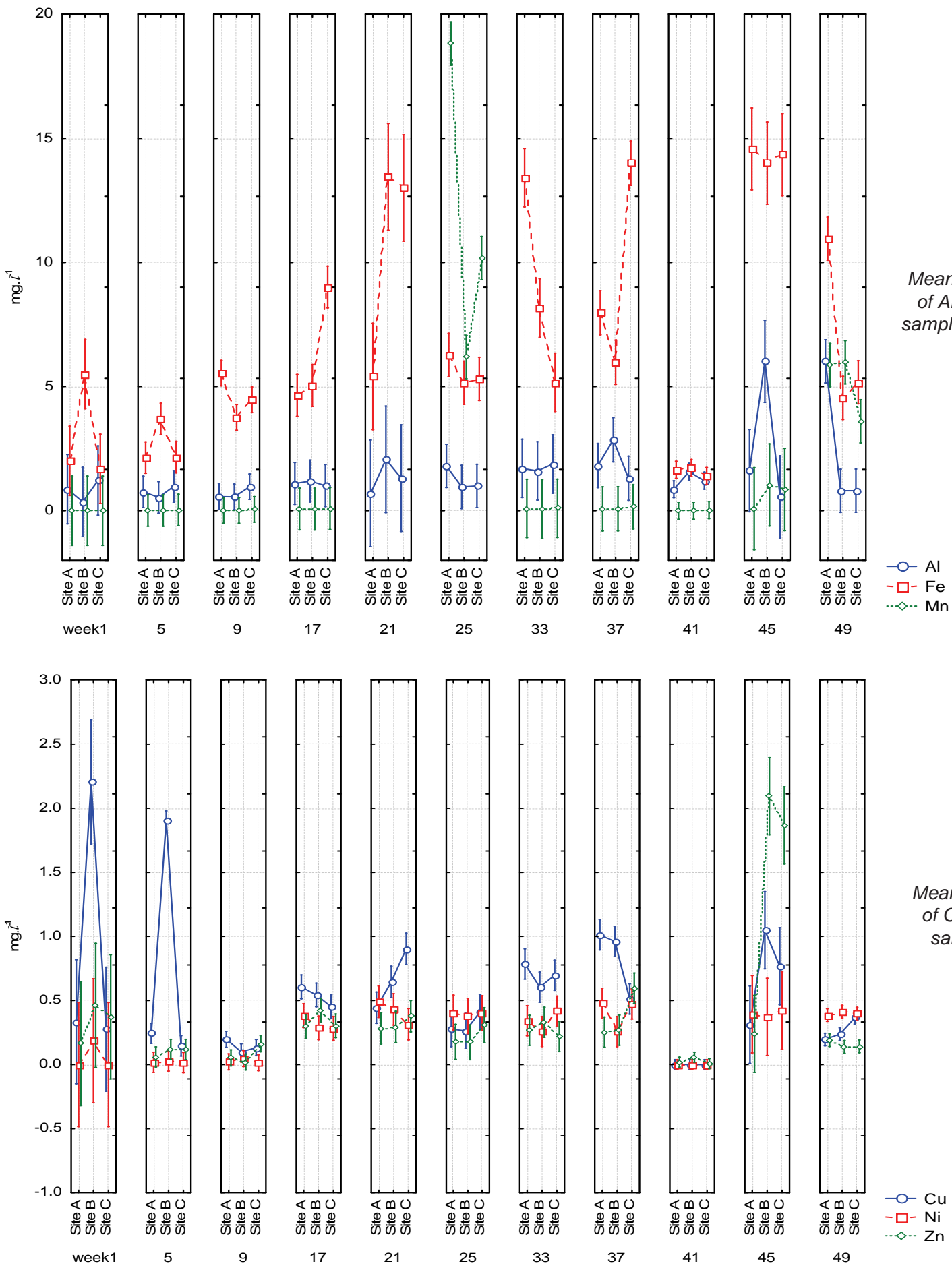

Figure 2A

Mean metal concentrations of $\mathrm{Al}, \mathrm{Fe}$ and $\mathrm{Mn}$ in water samples from the Berg River

Figure 2B

Mean metal concentrations of $\mathrm{Cu}, \mathrm{Ni}$ and $\mathrm{Zn}$ in water samples from the Berg River

\section{Statistical analysis}

The results presented are the averages of five repeats for each particular sampling point at the different sampling sites. For statistical analysis, dry mass ( 0.500 to $0.600 \mathrm{~g}$ ) and volume $(5 \mathrm{~m} \ell)$ were taken into consideration for the calculation of the final metal concentrations in a given sample. Repeated measures ANOVA (RMAs) were performed on all data obtained as outlined in Dunn and Clark (1987), using Statistica ${ }^{\mathrm{TM}}$. In each RMA, the residuals were analysed to determine whether they were normally distributed. In all hypothesis tests a significance level of $5 \%$ was used as standard.

\section{Results and discussion}

\section{Metals in water}

Comparisons of the mean metal concentrations in water are represented in Figs. 2A and B. The highest mean metal concentrations were recorded for $\mathrm{Mn}\left(18.8 \mathrm{mg} \cdot \ell^{-1}\right), \mathrm{Fe}\left(14.6 \mathrm{mg} \cdot \ell^{-1}\right)$ and Al (6 mg $\left.\ell^{-1}\right)$ during weeks 25, 45 and 49, respectively, at Site A. The concentrations of Al and Fe were significantly higher than the recommended guidelines of $\mathrm{Al}$ and $\mathrm{Fe}$ in freshwater systems as stipulated by the Department of Water Affairs and Forestry (DWAF, 1996) and the Canadian Council of Ministers 
of the Environment (CCME, 2001) (Table 1). Overall the mean concentrations for $\mathrm{Al}$ ranged from $0.4 \mathrm{mg} \cdot \ell^{-1}$ during Week 1 at Site B to $6 \mathrm{mg} \cdot \ell^{-1}$ during Week 49 at Site A, and for Fe from 1.7 $\mathrm{mg} \cdot \ell^{-1}$ during Week 1 at Site $C$ to $14.6 \mathrm{mg} \cdot \ell^{-1}$ during Week 45 at Site A (Table 1). The particular agricultural area, situated near the Berg River in the Western Cape uses the following pesticides and insecticides for the treatment of their crops: Acrobat ${ }^{\circledR} \mathrm{MZ}$, Copperflo, Cosavet, Folpan, Karathane, Mancozeb ${ }^{\mathrm{TM}}$, Phosguard $^{\mathrm{TM}}$. The increased concentrations of $\mathrm{Al}$ could be due to the use of Phosguard ${ }^{\mathrm{TM}}$, of which $\mathrm{Al}$ oxide is a component (Seachem, 2006). Phosguard ${ }^{\mathrm{TM}}$ is a porous adsorbent that removes phosphates, silicates, and other nutrients that support algae growth in this particular agricultural area.

Manganese concentrations fell within the recommended quality guideline range for most of the sampling period with the exception of Weeks 25, 45 and 49, where increased concentrations ranging from $3.6 \mathrm{mg} \cdot \ell^{-1}$ to $18.8 \mathrm{mg} \cdot \ell^{-1}$ at Sites $\mathrm{C}$ and A (Fig. 2), respectively, were recorded. Manganese is a major component of pesticides such as Mancozeb ${ }^{\mathrm{TM}}$ and Maneb. Mancozeb $^{\mathrm{TM}}$, then in turn, makes up $60 \%$ of the fungicide, Acrobat ${ }^{\circledR}$ $\mathrm{MZ}$, which is used to manage early and late blight in potatoes (Acrobat ${ }^{\circledR}$, 2005). Mancozeb, or manganese-zinc ethylene bis (dithiocarbamate), is a fungicide used for the treatment of plant diseases in the Western Cape. Its usage in agriculture amounts to $1343 \times 10^{3} \mathrm{~kg} / \mathrm{a}$ (Vermeulen et al., 2001). Contamination of

\section{TABLE 1}

Concentrations obtained in water of the Berg River compared to recommended safe concentrations as stipulated by the Department of Water Affairs and Forestry (1996) and the Canadian Council of Ministers of the Environment Quality Guidelines (2001)

\begin{tabular}{|l|c|c|c|}
\hline Metal & $\begin{array}{c}\text { Recommended } \\
\text { safe concentra- } \\
\text { tions as stipu- } \\
\text { lated by DWAF } \\
\left(\mathbf{1 9 9 6 )}\left(\mathbf{m g} \cdot \boldsymbol{\ell}^{-1} \text { ) }\right.\right.\end{array}$ & $\begin{array}{c}\text { Environmental } \\
\text { quality guidelines } \\
\text { as stipulated } \\
\text { by CCME (2001) } \\
\left(\mathbf{m g} \cdot \boldsymbol{\ell}^{-1}\right)\end{array}$ & $\begin{array}{c}\text { Mean meal } \\
\text { concentrations } \\
\text { obtained in water } \\
\left.\text { (mg } \cdot \boldsymbol{\ell}^{-1}\right)\end{array}$ \\
\hline $\mathrm{Al}$ & $0.1-0.15$ & $0.005-0.1$ & $0.4-6$ \\
\hline $\mathrm{Cu}$ & $0.002-0.012$ & $0.002-0.004$ & $0-2.2$ \\
\hline $\mathrm{Fe}$ & $\mathrm{N} / \mathrm{A}$ & 0.3 & $1.4-14.6$ \\
\hline $\mathrm{Mn}$ & 1.3 & $\mathrm{~N} / \mathrm{A}$ & $0-18.8$ \\
\hline $\mathrm{Ni}$ & $\mathrm{N} / \mathrm{A}$ & $0.025-0.15$ & $0-0.5$ \\
\hline $\mathrm{Pb}$ & $\mathrm{N} / \mathrm{A}$ & $0.001-0.007$ & $0-0$ \\
\hline $\mathrm{Zn}$ & 0.036 & 0.03 & $0.01-2.1$ \\
\hline
\end{tabular}

N/A = Data not available the water could be due to excessive use or improper discarding of these pesticides into the river (Agency for Toxic Substances and Disease Registry) (ATSDR, 2000). As previously mentioned, Site A (Fig. 1) is situated in an agricultural area and is the site at which the highest concentrations of metals were recorded. Runoff from a nearby farm enters the river at this site, which could account for the increase in Mn concentrations.

The recorded concentrations of $\mathrm{Cu}, \mathrm{Ni}$ and $\mathrm{Zn}$ in water samples varied throughout the study period (Table 1). Lead could not be detected in any of the analysed samples. The concentrations of $\mathrm{Cu}$, Ni and $\mathrm{Zn}$ fluctuated above and below the recommended guidelines of DWAF (1996) and the CCME (2001). The mean concentrations recorded for $\mathrm{Ni}$ were higher than the recommended concentrations during Weeks 17, 21, 25, 33, 37, 45 and 49. The recorded mean $\mathrm{Cu}$ and $\mathrm{Zn}$ concentrations fell within the recommended guidelines for Week 41 only (Table 1). The increases in $\mathrm{Zn}$ could also be as a result of Mancozeb ${ }^{\mathrm{TM}}$ use, as $\mathrm{Zn}$ is a component of this pesticide. The increased metal concentrations could also possibly be due to recurring anthropogenic episodes associated with the Berg River during the sampling period (Barnes, 2003).

\section{Metals in sediment}

Comparisons of the mean concentrations for $\mathrm{Al}$ and $\mathrm{Fe}$ are presented in Fig. 3. Results for $\mathrm{Cu}, \mathrm{Mn}, \mathrm{Ni}, \mathrm{Pb}$, and $\mathrm{Zn}$ are presented in Tables 2 and 3. No recommended sediment quality guidelines for $\mathrm{Al}, \mathrm{Fe}, \mathrm{Mn}, \mathrm{Pb}, \mathrm{Ni}, \mathrm{Cu}$ and $\mathrm{Zn}$ were available from DWAF (1996) and guidelines for $\mathrm{Cu}$ and $\mathrm{Zn}$ only were available from the Canadian Council of Ministers of the Environment (CCME, 2001). Significant differences $(\mathrm{p}<0.05)$ in the concentrations for $\mathrm{Al}$ and $\mathrm{Fe}$ were observed for the sediment samples. The highest mean concentration $\left(\mathrm{mg} \cdot \mathrm{kg}^{-1}\right.$ ) of $17448.8 \mathrm{mg} \cdot \mathrm{kg}^{-1}$ was recorded for Al during Week 1 at Site B (Fig. 3). In comparison to the results obtained for Week 1, no significant differences in concentrations $(p>0.05)$ of $\mathrm{Al}$ were recorded from Weeks 5 to 49, where mean concentrations ranged from 353.2 $\mathrm{mg} \cdot \mathrm{kg}^{-1}$ at Site A to $2687.7 \mathrm{mg} \cdot \mathrm{kg}^{-1}$ at Site C, both during Week 5 . The highest mean concentrations of $21035 \mathrm{mg} \cdot \mathrm{kg}^{-1}$ and 26473.3 $\mathrm{mg} \cdot \mathrm{kg}^{-1}$ were recorded for Fe in Weeks 1 and 5, at Sites B and C, respectively. In comparison to the results obtained for Weeks 1 and 5 , no significant $(p>0.05)$ differences in concentrations of Fe were recorded for Weeks 9 to 49, where the mean concentrations ranged from $700 \mathrm{mg} \cdot \mathrm{kg}^{-1}$ to $7014.9 \mathrm{mg} \cdot \mathrm{kg}^{-1}$, during Weeks 33 and 45, at Sites A and C, respectively.

\begin{tabular}{|c|c|c|c|c|c|c|c|c|c|}
\hline \multicolumn{10}{|c|}{$\begin{array}{l}\text { TABLE } 2 \\
\text { Mean metal concentrations of } \mathrm{Cu}, \mathrm{Mn} \text { and } \mathrm{Ni} \text { recorded in sediment samples for the different sampling weeks }\end{array}$} \\
\hline \multicolumn{10}{|c|}{ Metals $\left(\mathrm{mg}^{\prime} \mathrm{kg}^{-1}\right)$} \\
\hline Time (weeks) & & $\mathrm{Cu}$ & & & $\mathrm{Mn}$ & & & $\mathrm{Ni}$ & \\
\hline Sites & A & B & C & A & B & C & A & B & C \\
\hline 1 & $5.0 \pm 4.5$ & $74.0 \pm 0$ & $8.2 \pm 2.1$ & $3.0 \pm 0.5$ & $11.0 \pm 0$ & $11.0 \pm 0.9$ & $5.0 \pm 0.2$ & $44.0 \pm 0$ & $5.0 \pm 0.1$ \\
\hline 5 & $4.0 \pm 1.6$ & $3.8 \pm 1.8$ & $12.0 \pm 2.9$ & $5.0 \pm 0.6$ & $7.5 \pm 0.8$ & $70.0 \pm 5.8$ & $5.0 \pm 0.3$ & $5.0 \pm 0.4$ & $5.0 \pm 0.1$ \\
\hline 9 & $2.0 \pm 0.9$ & $3.2 \pm 1.8$ & $4.4 \pm 2.2$ & $3.0 \pm 0.5$ & $8.4 \pm 1.1$ & $12.0 \pm 3.4$ & $4.0 \pm 0.4$ & $5.0 \pm 0.5$ & $8.0 \pm 0.3$ \\
\hline 17 & $2.0 \pm 0.1$ & $5.9 \pm 2.5$ & $9.9 \pm 2.1$ & $7.0 \pm 0.6$ & $9.4 \pm 0.6$ & $12.0 \pm 0.7$ & $5.0 \pm 0.1$ & $5.0 \pm 0.2$ & $5.0 \pm 0.4$ \\
\hline 21 & $3.0 \pm 0.6$ & $3.3 \pm 0.4$ & $2.9 \pm 0.4$ & $5.0 \pm 1.3$ & $8.6 \pm 0.5$ & $13.0 \pm 2.5$ & $0.0 \pm 0.0$ & $0.0 \pm 0.0$ & $6.0 \pm 0.5$ \\
\hline 25 & $1.0 \pm 1.7$ & $12.0 \pm 1.9$ & $11.0 \pm 3$ & $8.0 \pm 0.4$ & $3.9 \pm 0.3$ & $13.0 \pm 0.9$ & $0.0 \pm 0.0$ & $0.4 \pm 0.0$ & $0.0 \pm 0.0$ \\
\hline 33 & $5.0 \pm 1.3$ & $4.9 \pm 0.9$ & $6.7 \pm 2.2$ & $3.0 \pm 0.2$ & $4.1 \pm 0.4$ & $5.9 \pm 0.4$ & $2.0 \pm 0.3$ & $2.0 \pm 0.4$ & $1.0 \pm 0.3$ \\
\hline 37 & $7.0 \pm 0.9$ & $6.3 \pm 0.8$ & $7.4 \pm 1.2$ & $7.0 \pm 0.9$ & $5.1 \pm 0.5$ & $15.0 \pm 2.3$ & $2.0 \pm 0.4$ & $2.0 \pm 0.3$ & $3.0 \pm 0.2$ \\
\hline 41 & $5.0 \pm 0.8$ & $4.9 \pm 1.3$ & $4.5 \pm 0.2$ & $9.0 \pm 0.7$ & $4.4 \pm 0.4$ & $19.0 \pm 1.4$ & $0.0 \pm 0.0$ & $0.0 \pm 0.0$ & $3.0 \pm 0.3$ \\
\hline 45 & $7.0 \pm 0.9$ & $6.7 \pm 1.6$ & $6.9 \pm 0.4$ & $11.0 \pm 0.6$ & $16.0 \pm 3.8$ & $43.0 \pm 7.2$ & $4.0 \pm 0.6$ & $5.0 \pm 0.5$ & $1.0 \pm 0.7$ \\
\hline 49 & $4.0 \pm 0.7$ & $2.9 \pm 0.7$ & $7.8 \pm 4.9$ & $7.0 \pm 0.2$ & $12.0 \pm 1.4$ & $44.0 \pm 1.4$ & $4.0 \pm 0.4$ & $4.0 \pm 0.3$ & $5.0 \pm 0.4$ \\
\hline
\end{tabular}



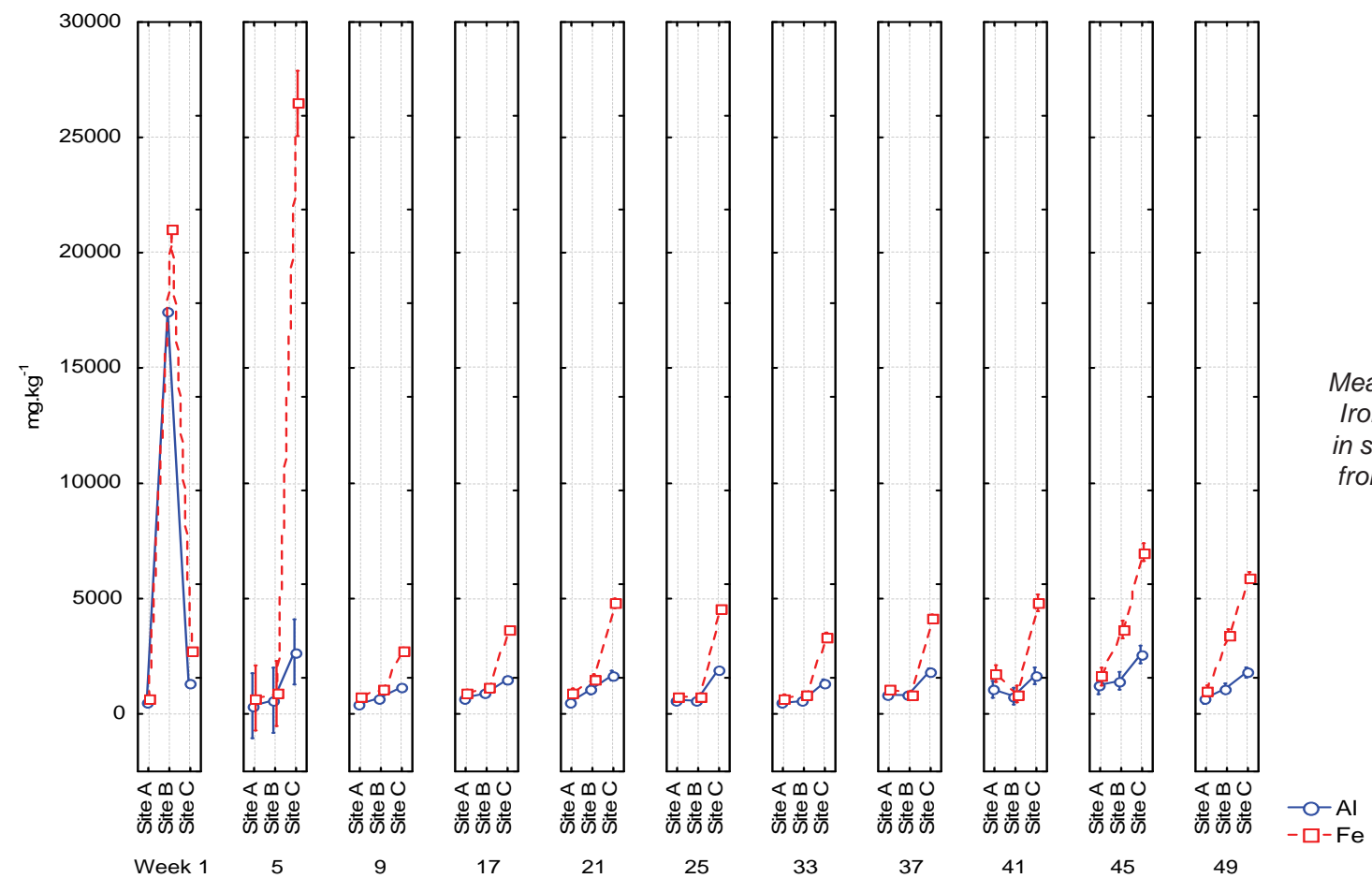

Figure 3

Mean Aluminium and Iron concentrations in sediment samples from the Berg River

\begin{tabular}{|c|c|c|c|c|c|c|c|c|c|}
\hline \multicolumn{10}{|c|}{$\begin{array}{c}\text { TABLE } 4 \\
\text { Mean metal concentrations of } \mathrm{Cu}, \mathrm{Mn} \text { and } \mathrm{Ni} \text { recorded in biofilm samples for the different sampling weeks }\end{array}$} \\
\hline \multicolumn{10}{|c|}{ Metals $\left(\mathrm{mg} \cdot \mathrm{I}^{-1}\right)$} \\
\hline Time (weeks) & \multicolumn{3}{|c|}{$\mathrm{Cu}$} & \multicolumn{3}{|c|}{ Mn } & \multicolumn{3}{|c|}{$\mathrm{Ni}$} \\
\hline Sites & A & B & C & A & B & C & A & B & C \\
\hline 1 & $1.0 \pm 0.2$ & $1.7 \pm 0.2$ & $2.0 \pm 0.5$ & $2.6 \pm 0.9$ & $1.4 \pm 0.1$ & $9.0 \pm 0.8$ & $0.4 \pm 0.1$ & $0.3 \pm 0.0$ & $0.3 \pm 0.0$ \\
\hline 5 & $1.0 \pm 0.1$ & $0.2 \pm 0.0$ & $1.0 \pm 0.1$ & $2.2 \pm 0.2$ & $1.1 \pm 0.1$ & $11.0 \pm 0.3$ & $0.5 \pm 0.0$ & $0.4 \pm 0.0$ & $0.7 \pm 0.0$ \\
\hline 9 & $1.0 \pm 0.1$ & $0.7 \pm 0.2$ & $1.0 \pm 0.2$ & $4.9 \pm 0.3$ & $2.0 \pm 0.1$ & $32.0 \pm 1.4$ & $0.6 \pm 0.0$ & $0.6 \pm 0.0$ & $0.9 \pm 0.0$ \\
\hline 17 & $1.5 \pm 0.2$ & $0.8 \pm 0.1$ & $1.0 \pm 0.1$ & $17.0 \pm 3.1$ & $8.4 \pm 1.3$ & $9.0 \pm 1.2$ & $19.0 \pm 41.0$ & $0.6 \pm 0.0$ & $0.7 \pm 0.1$ \\
\hline 21 & $0.0 \pm 0.0$ & $0.5 \pm 0.1$ & $0.0 \pm 0.0$ & $1.4 \pm 0.4$ & $4.6 \pm 0.8$ & $8.0 \pm 0.5$ & $0.0 \pm 0.0$ & $0.0 \pm 0.0$ & $0.0 \pm 0.0$ \\
\hline 25 & $1.0 \pm 0.1$ & $0.7 \pm 0.1$ & $1.0 \pm 0.2$ & $71.0 \pm 17.0$ & $1.7 \pm 0.2$ & $6.0 \pm 0.4$ & $1.0 \pm 0.1$ & $0.4 \pm 0.0$ & $0.5 \pm 0.0$ \\
\hline 33 & $0.3 \pm 0.0$ & $0.4 \pm 0.1$ & $0.0 \pm 0.0$ & $0.7 \pm 0.0$ & $1.4 \pm 0.2$ & $3.0 \pm 0.3$ & $0.0 \pm 0.0$ & $3.0 \pm 5.8$ & $0.0 \pm 0.0$ \\
\hline 37 & $2.0 \pm 0.2$ & $0.4 \pm 0.0$ & $1.0 \pm 0.1$ & $13.0 \pm 1.5$ & $2.2 \pm 0.5$ & $9.0 \pm 1.2$ & $0.5 \pm 0.0$ & $0.0 \pm 0.0$ & $0.1 \pm 0.0$ \\
\hline 41 & $1.0 \pm 0.0$ & $0.4 \pm 0.1$ & $0.0 \pm 0.1$ & $3.4 \pm 0.4$ & $1.6 \pm 0.2$ & $4.0 \pm 0.2$ & $0.0 \pm 0.0$ & $0.0 \pm 0.0$ & $0.0 \pm 0.0$ \\
\hline 45 & $1.0 \pm 0.1$ & $0.6 \pm 0.1$ & $0.0 \pm 0.1$ & $1.2 \pm 0.1$ & $1.8 \pm 0.4$ & $5.0 \pm 0.8$ & $0.7 \pm 0.0$ & $1.0 \pm 0.1$ & $0.4 \pm 0.0$ \\
\hline 49 & $1.0 \pm 0.1$ & $0.7 \pm 0.0$ & $0.0 \pm 0.1$ & $0.8 \pm 0.0$ & $1.3 \pm 0.2$ & $4.8 \pm 0.1$ & $0.6 \pm 0.1$ & $0.4 \pm 0.0$ & $0.3 \pm 0.0$ \\
\hline
\end{tabular}

The Agency for Toxic Substances and Disease Registry (ATSDR, 1995) reported that Al comprises 8\% of the earth's crust, with dissolved $\mathrm{Al}$ and Fe primarily derived from soils (Neal et al., 1997). In addition, Al forms complexes with organic matter in soil, which could contribute to elevated concentrations (Tipping et al., 1991).

Effluent from a nearby stormwater drain enters the river at Site $\mathrm{B}$, where the highest concentration of $\mathrm{Al}$ was recorded in Week 1. The high concentrations of $\mathrm{Al}$ and Fe in the sediment samples could partly be due to the leaching of metals from housing materials and household products, utilised by inhabitants of the informal settlements, into the river. In addition, the galvanised sheeting used to build informal dwellings is primarily composed of Fe. When pure iron reacts readily with oxygen and moisture in the environment, a red or brown ferric oxide coating is formed, which destructively corrodes the galvanised sheeting. Excess Fe in aqueous environments can be the cause of chronic and acute health effects, but according to the Department of Water Affairs and Forestry, accidental Fe poisoning is rare (DWAF, 1996).
Tables 2 and 3 represent the mean concentrations for $\mathrm{Cu}$, $\mathrm{Mn}, \mathrm{Ni}, \mathrm{Pb}$ and $\mathrm{Zn}$. Manganese, $\mathrm{Ni}$ and $\mathrm{Pb}$ concentrations were significantly low throughout the study period with the highest mean metal concentrations for $\mathrm{Mn}, \mathrm{Ni}$ and $\mathrm{Pb}$ recorded at: $70 \mathrm{mg} \cdot \mathrm{kg}^{-1}$ in Week 5 at Site C; $44 \mathrm{mg} \cdot \mathrm{kg}^{-1}$ in Week 1 at Site B and $23 \mathrm{mg} \cdot \mathrm{kg}^{-1}$ in Week 45 at Site B (Tables 2 and 3), respectively. No recommended sediment quality guidelines for $\mathrm{Pb}$, $\mathrm{Mn}$ and Ni were available from DWAF (1996) and the CCME (2001).

The highest mean $\mathrm{Cu}$ concentration of $74 \mathrm{mg} \cdot \mathrm{kg}^{-1}$ was recorded at Site B, during the first sampling week (Table 2). This result for $\mathrm{Cu}$ was higher than the recommended environmental quality guideline of $35.7 \mathrm{mg} \cdot \mathrm{kg}^{-1}$ in freshwater sediment as specified by the CCME (2001). Thereafter, during Weeks 5 to 49 , concentrations for $\mathrm{Cu}$ decreased significantly $(\mathrm{p}<0.05)$, to levels lower than the guideline (CCME, 2001).

The highest mean $\mathrm{Zn}$ concentration of $395 \mathrm{mg} \cdot \mathrm{kg}^{-1}$ was recorded at Site B, during Week 1 (Table 3). This result was higher than the recommended Canadian sediment quality guide- 

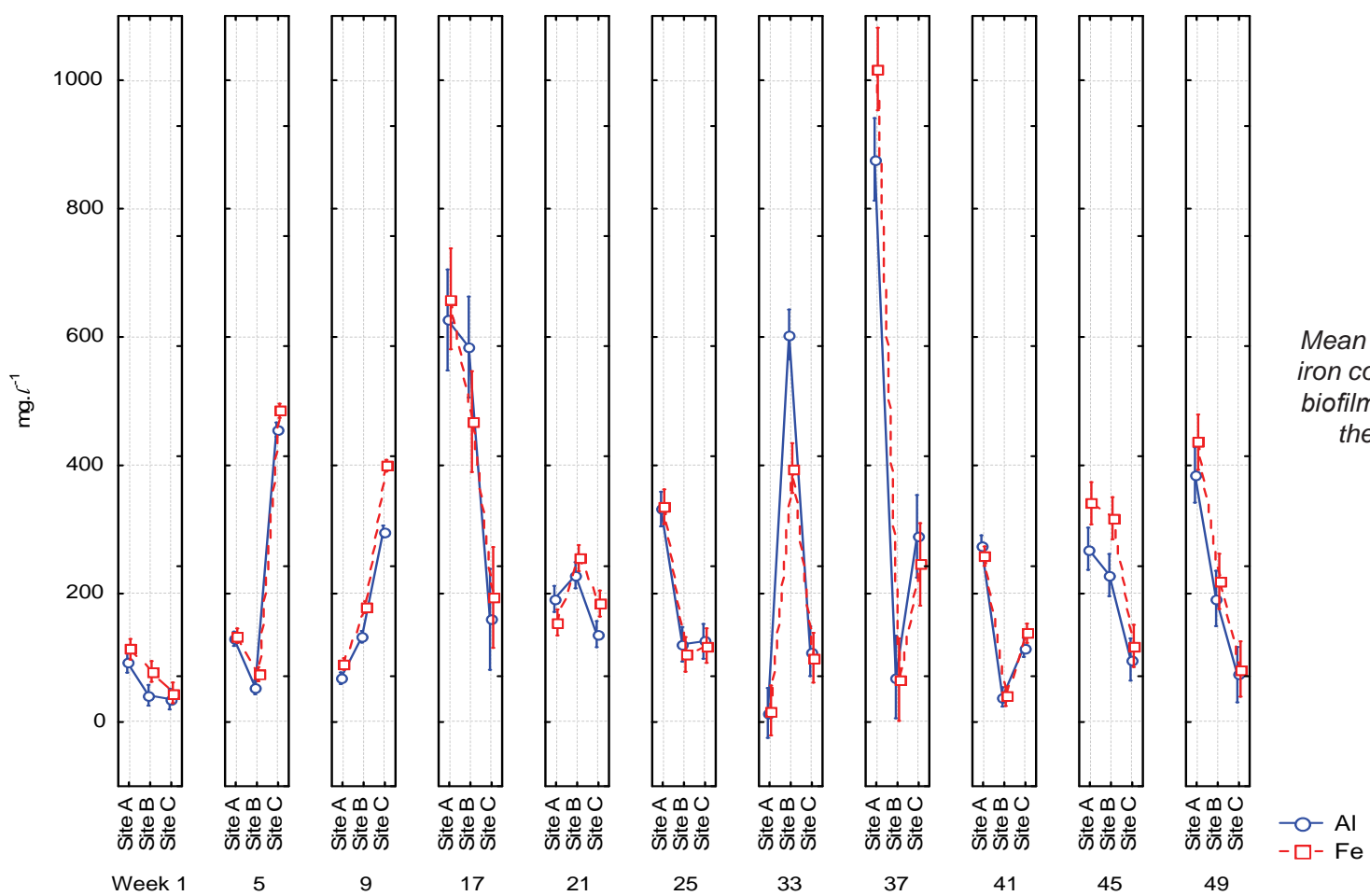

Figure 4 ron concentrations in biofilm samples from the Berg River

lines of $123 \mathrm{mg} \cdot \mathrm{kg}^{-1}$ (CCME, 2001). During the subsequent sampling weeks the mean $\mathrm{Zn}$ concentrations ranged from 4 to $36 \mathrm{mg} \cdot \mathrm{kg}^{-1}$ (Table 3), which falls within the accepted CCME guidelines. During Week 1 of sampling the region experienced very low rainfall $(6 \mathrm{~mm})$. In the following weeks, the recorded rainfall ranged between $52.2 \mathrm{~mm}$ and $154 \mathrm{~mm}$. The lower rainfall could imply that the metals were not readily available in the water column, impeding metal transfer from site to site and increasing metal accumulation in the sediment.

\section{Metals in biofilm}

No recommended biofilm quality guidelines were available from DWAF (1996) and the Canadian Council of Ministers of the Environment (CCME, 2001). Biofilms are layers of organisms, organic matter and inorganic material, organised within EPS (Decho, 1990). These organisms attach and develop on biologically active or non-active surfaces (Stickler, 1999).

Comparisons of the mean concentrations for $\mathrm{Al}$ and $\mathrm{Fe}$ are presented in Fig. 4. Results for $\mathrm{Cu}, \mathrm{Mn}, \mathrm{Ni}, \mathrm{Pb}$, and $\mathrm{Zn}$ are represented in Tables 4 and 5 . The highest metal concentrations recorded in the biofilm samples $\left(\mathrm{mg} \cdot \ell^{-1}\right)$, were for $\mathrm{Al}$ and $\mathrm{Fe}$, as in the case of sediment. Throughout the entire study period, $\mathrm{Fe}$ was consistently present in elevated concentrations in water, sediment and biofilm samples when compared to the other metals analysed for. The recorded results for $\mathrm{Fe}$ and $\mathrm{Al}$ fluctuated throughout the entire study period. The mean concentrations recorded for $\mathrm{Al}$ ranged from $14.1 \mathrm{mg} \cdot \ell^{-1}$ during Week 33 to $876.8 \mathrm{mg} \cdot \ell^{-1}$, during Week 37, both at Site A (Fig. 4). In addition, the mean Fe concentrations in biofilm samples ranged from 18 $\mathrm{mg} \cdot \ell^{-1}$ during Week 33 to $1017.5 \mathrm{mg} \cdot \ell^{-1}$ during Week 37, again both at Site A (Fig. 4).

As indicated above, an increase in the concentrations of $\mathrm{Al}$ and Fe in the biofilm samples was observed at Site A in Week 37. For the same time period, a corresponding study investigating microbial contamination of the river revealed a microbial count in sessile samples of $3.9 \times 10^{-7}$ organisms. This increased number

of micro-organisms could have facilitated the $\mathrm{Al}$ and $\mathrm{Fe}$ accumulation in the biofilm. It is well recognised that micro-organisms have developed unique means of resistance to specific metals (Roanne and Pepper, 2000), the mechanisms of which are not yet fully understood. Extracellular polymeric substances contain various constituents such as polysaccharides, proteins, nucleic acids, lipids or humic substances (Mayer et al., 1999). Decho (1990) showed that the EPS assists in the bacterial survival by providing protection against predation and environmental fluctuations.

Tables 4 and 5, represents the metal concentrations recorded in biofilm samples for $\mathrm{Cu}, \mathrm{Mn}, \mathrm{Ni}, \mathrm{Pb}$ and $\mathrm{Zn}$. These metal concentrations were consistently lower than the concentrations recorded for $\mathrm{Al}$ and $\mathrm{Fe}$. The highest mean metal concentrations for $\mathrm{Cu}, \mathrm{Mn}, \mathrm{Ni}, \mathrm{Pb}$ and $\mathrm{Zn}$ were recorded at: $2 \mathrm{mg} \cdot \ell^{-1}$ in Weeks 1 and 37 at Sites $C$ and A; $71 \mathrm{mg} \cdot \ell^{-1}$ in Week 25 at Site A; $19 \mathrm{mg} \cdot \ell^{-1}$ in Week 17 at Site A; $1.6 \mathrm{mg} \cdot \ell^{-1}$ in Week 5 at Site $C$ and $8.4 \mathrm{mg} \cdot \ell^{-1}$ in Week 25 at Site A, respectively (Tables 4 and 5).

Kröpfl et al. (2006) studied metal accumulation by biofilms in the Tisza River, Hungary. The authors utilised different substrates to cultivate biofilms, with the aim of investigating the applicability of biofilms as biomonitors. The different substrates used were andesite, polished granite, Plexi-glass, granite and polycarbonate. The biofilms were cultivated for six weeks, after which, the samples were analysed using total reflection $\mathrm{x}$ ray fluorescence (TXRF) for elemental analysis. The concentrations of essential elements and heavy metal pollutants $(\mathrm{Cu}, \mathrm{Ni}$, $\mathrm{Pb}$ and $\mathrm{Zn}$ ) were highest in biofilms on polished granite or granite (rocks and stones) (Kröpfl et al., 2006). In the present study, various substrates such as rocks, leaves, glass and stones were collected as representative biofilm samples form the Berg River. Biofilms are currently being studied as biomonitors in ecological research, but it is important to note that as yet no guidelines exist for biofilms in aquatic systems.

Research has shown that the EPS layer also exhibits a high metal absorption capacity. A study by Suh et al. (1999) investigated the accumulation of $\mathrm{Pb}^{2+}$ into the EPS layer of pure species 


\begin{tabular}{|c|c|c|c|c|c|c|}
\hline \multicolumn{7}{|c|}{$\begin{array}{l}\text { TABLE } 3 \\
\text { Mean metal concentrations of } \mathrm{Pb} \text { and } \mathrm{Zn} \text { recorded in sediment samples for the different sampling weeks }\end{array}$} \\
\hline \multicolumn{7}{|c|}{ Metals $\left(\mathrm{mg}^{\prime} \mathrm{kg}^{-1}\right)$} \\
\hline Time (weeks) & & $\mathrm{Pb}$ & & & $Z n$ & \\
\hline Sites & A & $\mathrm{B}$ & $\mathrm{C}$ & A & B & $\mathrm{C}$ \\
\hline 1 & $0.0 \pm 0.0$ & $2.0 \pm 0.3$ & $2.1 \pm 0.3$ & $7.6 \pm 1.4$ & $395.0 \pm 0.0$ & $11.0 \pm 0.5$ \\
\hline 5 & $2.0 \pm 1.3$ & $2.0 \pm 0.6$ & $11.0 \pm 1.7$ & $6.5 \pm 0.7$ & $12.0 \pm 2.3$ & $22.0 \pm 2.3$ \\
\hline 9 & $1.0 \pm 0.8$ & $2.0 \pm 1.9$ & $3.0 \pm 0.4$ & $7.0 \pm 1.4$ & $11.0 \pm 2.3$ & $11.0 \pm 1.4$ \\
\hline 17 & $3.0 \pm 2.2$ & $2.0 \pm 0.2$ & $3.0 \pm 0.4$ & $8.5 \pm 0.5$ & $9.5 \pm 0.5$ & $9.0 \pm 1.4$ \\
\hline 21 & $1.0 \pm 0.3$ & $3.0 \pm 0.4$ & $4.2 \pm 0.7$ & $4.3 \pm 0.8$ & $9.2 \pm 0.8$ & $7.3 \pm 0.9$ \\
\hline 25 & $3.0 \pm 0.4$ & $2.0 \pm 0.2$ & $4.2 \pm 0.3$ & $13.0 \pm 1.4$ & $9.2 \pm 0.5$ & $11.0 \pm 0.9$ \\
\hline 33 & $2.0 \pm 0.5$ & $2.0 \pm 0.3$ & $2.9 \pm 0.6$ & $4.0 \pm 2.1$ & $3.8 \pm 0.4$ & $6.2 \pm 0.7$ \\
\hline 37 & $3.0 \pm 0.6$ & $3.0 \pm 0.5$ & $4.9 \pm 0.3$ & $8.6 \pm 0.5$ & $10.0 \pm 0.7$ & $11.0 \pm 1.3$ \\
\hline 41 & $4.0 \pm 0.6$ & $3.0 \pm 0.3$ & $4.6 \pm 2.6$ & $13.0 \pm 1.0$ & $12.0 \pm 0.9$ & $14.0 \pm 2.3$ \\
\hline 45 & $5.0 \pm 1.5$ & $23 \pm 34$ & $8.9 \pm 6.8$ & $19.0 \pm 2.5$ & $23.0 \pm 7.9$ & $16.0 \pm 1.3$ \\
\hline 49 & $2.0 \pm 0.4$ & $6.0 \pm 2.9$ & $5.1 \pm 0.6$ & $12.0 \pm 1.0$ & $27.0 \pm 6.7$ & $36.0 \pm 41.0$ \\
\hline
\end{tabular}

\begin{tabular}{|c|c|c|c|c|c|c|}
\hline \multicolumn{7}{|c|}{ TABLE 5} \\
\hline \multicolumn{7}{|c|}{ Metals $\left(\mathrm{mg} \cdot \ell^{-1}\right)$} \\
\hline Time (weeks) & & $\mathbf{P b}$ & & & $\mathrm{Zn}$ & \\
\hline Sites & A & B & C & A & B & C \\
\hline 1 & $0.4 \pm 0.1$ & $0.0 \pm 0.0$ & $0.2 \pm 0.0$ & $2.0 \pm 0.5$ & $2.0 \pm 0.2$ & $1.0 \pm 0.1$ \\
\hline 5 & $0.4 \pm 0.0$ & $0.2 \pm 0.0$ & $1.61 \pm 0.1$ & $2.0 \pm 0.2$ & $2.0 \pm 0.1$ & $5.0 \pm 0.2$ \\
\hline 9 & $1.3 \pm 0.2$ & $0.6 \pm 0.0$ & $1.2 \pm 0.1$ & $2.0 \pm 0.1$ & $3.0 \pm 0.2$ & $6.0 \pm 0.3$ \\
\hline 17 & $0.3 \pm 0.0$ & $0.9 \pm 0.1$ & $0.5 \pm 0.1$ & $5.6 \pm 1.0$ & $3.0 \pm 0.5$ & $2.0 \pm 0.3$ \\
\hline 21 & $1.3 \pm 0.2$ & $0.7 \pm 0.1$ & $0.4 \pm 0.1$ & $0.0 \pm 0.0$ & $2.0 \pm 0.4$ & $1.0 \pm 0.2$ \\
\hline 25 & $0.0 \pm 0.0$ & $0.2 \pm 0.0$ & $0.3 \pm 0.1$ & $8.4 \pm 1.0$ & $1.0 \pm 0.1$ & $2.0 \pm 0.2$ \\
\hline 33 & $0.2 \pm 0.1$ & $0.3 \pm 0.0$ & $0.2 \pm 0.0$ & $0.5 \pm 0.0$ & $1.0 \pm 0.2$ & $1.0 \pm 0.1$ \\
\hline 37 & $0.7 \pm 0.1$ & $0.2 \pm 0.0$ & $0.7 \pm 0.1$ & $8.0 \pm 0.1$ & $1.0 \pm 0.1$ & $2.0 \pm 0.3$ \\
\hline 41 & $0.7 \pm 0.1$ & $0.0 \pm 0.0$ & $0.2 \pm 0.0$ & $3.0 \pm 0.7$ & $1.0 \pm 0.2$ & $1.0 \pm 0.3$ \\
\hline 45 & $0.9 \pm 0.1$ & $0.6 \pm 0.1$ & $0.1 \pm 0.1$ & $5.0 \pm 0.6$ & $3.0 \pm 0.5$ & $1.0 \pm 0.1$ \\
\hline 49 & $1.4 \pm 0.4$ & $0.5 \pm 0.0$ & $0.0 \pm 0.0$ & $6.0 \pm 1.4$ & $3.0 \pm 0.2$ & $1.0 \pm 0.1$ \\
\hline
\end{tabular}

Aureobasidium pullulans biofilms using transmission electron microscopy (TEM). The results of the study showed that the EPS was responsible for more than $90 \%$ of $\mathrm{Pb}^{2+}$ accumulation of the total $\mathrm{Pb}$ dissolved. The TEM microphotographs showed that the $\mathrm{Pb}^{2+}$ penetrated the cell wall, cell membrane and even into the inner cellular parts of the cell.

Prat et al. (1999) studied the recovery of an aquatic ecosystem after toxic mining waste was dumped into the Guadiamar River Basin, Seville, Spain in April 1998. Nine sites were sampled, three of which were unaffected and designated as the control or reference sites. Sampling was carried out over a period of five months, in the form of plankton and particulate material, naturally occurring biofilms and macroinvertebrates obtained from water, riffles (stones), introduced artificial substrates (large tiles), vegetation and sediment. These samples were analysed for water quality and for arsenic (As), cadmium (Cd), antimony (Sb), thallium ( $\mathrm{Tl}), \mathrm{Cu}, \mathrm{Pb}$ and $\mathrm{Zn}$ concentrations, as these were the most abundant heavy metals in the mine spill. Compared to the reference stations, the concentrations of metals were higher in the polluted sites, with $\mathrm{As}, \mathrm{Cu}, \mathrm{Pb}$ and $\mathrm{Zn}$, being the most abundant. Except for $\mathrm{Cd}, \mathrm{Cu}$ and $\mathrm{Sb}$, all the other metals in biofilms from the polluted sites were found to be more than 15 times higher than in the reference stations (Prat et al., 1999). In addition, the metal concentrations recorded in the biofilm samples were 5 to 20 times higher than the recorded values in macroinvertebrates (Prat et al., 1999). This study proved that biofilms are effective in the accumulation of metals from the environment.

\section{Conclusions}

The conclusions of this study were as follows:

- $\mathrm{Al}$ and Fe were recorded at consistently higher concentrations than all the other metals analysed for in water, sediment and biofilm samples

- In both the sediment and biofilm samples, the concentrations of $\mathrm{Al}$ and $\mathrm{Fe}$ were significantly higher $(\mathrm{p}<0.05)$ than $\mathrm{Cu}$, $\mathrm{Zn}, \mathrm{Pb}, \mathrm{Ni}$, and $\mathrm{Mn}$

- On average, the results generated for water for $\mathrm{Al}$ and $\mathrm{Fe}$, were higher than the quality guidelines recommended by DWAF (1996) and the CCME (2001)

- The results for $\mathrm{Cu}$ and $\mathrm{Zn}$ were higher than the recommended quality guidelines in freshwater sediment (CCME, 2001). No guidelines for $\mathrm{Al}, \mathrm{Fe}, \mathrm{Mn}, \mathrm{Pb}$ and $\mathrm{Ni}$ in sediment were available.

- The highest metal concentrations were obtained in the sediment and biofilm samples, yet no freshwater guidelines for metals in sediment were available from DWAF and no guidelines for metal concentrations in biofilms were available from either DWAF or the CCME.

\section{Future research}

Future research would include the setting-up of parameters or guidelines for acceptable metal concentrations in rivers. Research at the Cape Peninsula University of Technology is 
currently being conducted on the Lourens-, the Diep-, the Kuilsand the Plankenbrug Rivers, as well as the Berg River, as discussed in this article.

\section{Acknowledgements}

The authors wish to thank the Paarl Municipality for their assistance in sample collection and the National Research Foundation (NRF) for financial support.

\section{References}

ACROBAT ${ }^{\circledR}$ MZ (2005) Fungicide for use on potatoes and flue cured tobacco. Cited online at >URL file://E:|pesticide $\backslash A C R O B A T$ MZ.htm (Accessed 2006/12/11).

AGENCY FOR TOXIC SUBSTANCES AND DISEASE REGISTRY (ATSDR) (1995) Aluminium, Material Safety Data Sheet. Atlanta, Georgia, USA.

AGENCY FOR TOXIC SUBSTANCES AND DISEASE REGISTRY (ATSDR) (2000) Toxicological Profile for Manganese. US Depart ment of Health and Human Services, Public Health Service. Atlanta, Georgia, USA.

ALLOWAY BJ (1995a) Soil processes and the behaviour of metals. In: Alloway BJ (ed.) Heavy Metals in Soils (2 ${ }^{\text {nd }}$ edn.) Blackie Academic and Professional, London, England. 6-37.

ALLOWAY BJ (1995b) The origins of heavy metals in soils. In: Alloway BJ (ed.) Heavy Metals in Soil (2nd edn.) Blackie Academic and Professional, London, England. 38-57.

BARNES JM (2003) The Impact of Water Pollution from Formal and Informal Urban Developments along the Plankenbrug River on Water Quality and Health Risk. Ph.D. Dissertation, Department of Community Health, University of Stellenbosch, South Africa.

BROOKS BW, FORAN CM, RICHARDS SM, WESTON J, TURNER PK, STANLEY JK, SOLOMON KR, SLATTERY M and LA PONT TW (2003) Aquatic ecotoxicology of fluoxetine. Toxicol. Lett. 142 169-183.

CANADIAN COUNCIL OF MINISTERS OF THE ENVIRONMENT (CCME) (2001) Canadian Sediment quality Guidelines for the Protection of Aquatic Life: Summary Tables. Updated in: Canadian Environmental Quality Guidelines, 1999. Canadian Council of Ministers of the Environment, Winnipeg, Canada.

COSTERTON JW, GEESEY GG and CHENG KJ (1978) How bacteria stick. Sci. Amer. 238 86-95.

DE BEER D, SRINIVASAN R and STEWARD PS (1994) Direct measurement of chlorine penetration into biofilms during disinfection. Appl. Environ. Microbiol. 60 4339-4344.

DECHO AW (1990) Microbial exopolymer secretions in ocean environments: Their role(s) in food webs and marine processes. Oceanogr. Mar. Biol. Annu. Rev. 28 73-153.

DEPARTMENT OF WATER AFFAIRS and FORESTRY (DWAF) (1996) South African Water Quality Guidelines, Aquatic Ecosystems. (Vol. 7) Government Printer, Pretoria, South Africa.

DORIGO U, BOURRAIN X, BERARD A and LEBOULANGER C (2004) Seasonal changes in the sensitivity of river microalgae to atrazine and isoproturon along a contamination gradient. Sci. Tot. Environ. 318 101-114.

DUNN OJ and CLARK VA (1987) Applied Statistics: Analysis of Variance and Regression ( $2^{\text {nd }}$ edn.). John Wiley and Sons, London, England.

FRIBERG L, NORDBERG GF, KESSLER E and VOUK VB (eds.) (1986) Handbook of the Toxicology of Metals ( $2^{\text {nd }}$ edn.), Vols 1 and 2. Elsevier Science, Amsterdam Publishers, Amsterdam, Netherlands. 6.

FRIESE K, MAGES M, WENDT-POTTHOFF K and NUE T (1997) Determination of heavy metals in biofilms of the Elbe River by total reflection x-ray fluorescence spectrometry. Spectrochim. Acta. 5 1019-1025.
GEESEY GG, BREMER PJ, SMITH JJ, MUEGGE M and JANG LK (1992) Twophase model for describing the interactions between copper ions and exopolymers from Alteromonas atlantica. Can. J. Microbiol. 38 785-793.

HUANG C, YU FP, MCFETERS GA and STEWART PS (1995) Nonuniform spatial patterns of respiratory activity within biofilms during disinfection. Appl. Environ. Microbiol. 6 2252-2256.

KRÖPFL K, VLADÁR P, SZABO K, ÁCS É, BORSODI A, SZIKORA S, CAROLI S and ZÁRAY G (2006) Chemical and biological characterisation of biofilms formed on different substrata in Tisza River, Hungary. Environ. Pollut. 144 626-631.

MAYER C, MORITZ R, KIRSCHNER C, BORCHAND W, MAIBAUM R, WINGENDER J and FLEMMING H-C (1999) The role of intermolecular interactions: studies on molecular systems for bacterial biofilms. Intern. J. Biol. Macromol. 26 3-16.

MOWAT FS and BUNDY KJ (2001) Correlation of field-measured toxicity with chemical concentration and pollutant availability. Environ. Intern. 27 479-489.

NEAL C, ROBSON AJ, HARROW M, HILL L, WICKHAM H, BHARDWAJ CL, TINDALL CI, RYLAND GP, LEACH DV, JOHNSON RC, BRONSDON RK and CRANSTON M (1997) Major, minor, trace element and suspended sediment variations in the River Tweed: results from the LOIS core monitoring programme. Sci. Tot. Environ. 194/195 193-205.

NELSON YM, LION LW, SHULER ML and GHIORSE WC (1996) Modelling oligotrophic biofilm formation and lead adsorption to biofilm components. Environ. Sci. Technol. 30 2027-2035.

NEU TR (1992) Polysaccharide in biofilm. In: Prave P, Schlingmann M, Esser K, Thauer R and Wagner F (eds.) Jahrbuch. Biotechnologie. (Vol. 4) Carl Hanser, Munich, Germany. 73.

PRAT N, TOJA J, SOLÁ C, BURGOS MD, PLANS M and RIERADEVALL M (1999) Effect of dumping and cleaning activities on the aquatic ecosystems of the Guadiamar River following a toxic flood. Sci. Tot. Environ. 242 231-248.

ROANNE TM and PEPPER IL (2000) Microorganisms and metal pollutants. In: Maier RM, Pepper IL and Gerba CP (eds.) Environmental Microbiology. Academic Press, Elsevier, San Diego, USA. 403.

RIVER HEALTH PROGRAMME (2004) State-of-Rivers Report: Berg River System. Department of Water Affairs and Forestry, Pretoria.

SALEH MA, EWANE E, JONES J and WILSON BL (2000) Monitoring Wadi El Raiyan lakes of the Egyptian desert for inorganic pollutants by Ion-selective electrodes, Ion chromatography and Inductively Coupled Plasma Spectroscopy. Ecotoxicol. Environ. Saf. 45 310316

SEACHEM (2006) Phosguard ${ }^{\mathrm{TM}}$ Support. Cited online at > URL file:// E: pesticide $\backslash$ Phosguard FAQ.htm (Accessed 2006/12/11).

SOUTH AFRICAN BUREAU OF STANDARDS (2001) South African Bureau of Standards Specification for Drinking Water $\left(5^{\text {th }}\right.$ edn.) SABS 241. Pretoria, South Africa.

STICKLER D (1999) Biofilms. Curr. Op. Microbiol. 2 270-275.

SUH JH, YUN JW, KIM DS (1999) Effect of extracellular polymeric substances (EPS) on $\mathrm{Pb}^{2+}$ accumulation by Aureobasidium pullulans. Bioprocess Eng. 21 1-4.

TIPPING E, WOOF C and HURLEY MA (1991) Humic substances in acid surface waters; modelling aluminium binding, contribution to ionic charge-balance, and control of pH. Water Res. 25 425-435.

VERMEIREN K, VANDECASTEELE C and DAMS R (1990) Determination of trace amounts of cadmium, lead, copper and zinc in natural waters by Inductively Coupled Plasma Emission Spectrometry with thermospray nebulisation, after enrichment on chelex100. Analyst 115 17-22.

VERMEULEN LA, REINECKE AJ and REINECKE SA (2001) Evaluation of the fungicide manganese-zinc ethylene bis(dithiocarbamate) (Mancozeb) for sublethal and acute toxicity to Eisenia fetida (Oligochaeta). Ecotox. Environ. Saf. 48 183-189.

WORLD HEALTH ORGANISATION (1991) Inorganic Mercury (Environmental Health Criteria), International Program on Chemical Safety (Vol. 118) Geneva. 